\title{
Effects of Different Zinc Sources on Performance, Bio Distribution of Minerals and Expression of Genes Related to Metabolism of Broiler Chickens
}

\author{
Doaa Ibrahim ${ }^{1 *}$, Haytham A. Ali ${ }^{2}$, Shefaa A.M. El-Mandrawy ${ }^{3}$ \\ ${ }^{1}$ Department of Nutrition and Clinical Nutrition, Faculty of Veterinary Medicine, Zagazig \\ University, Egypt \\ ${ }^{2}$ Department of Biochemistry, Faculty of Veterinary Medicine, Zagazig University, Egypt \\ ${ }^{3}$ Department of Clinical Pathology, Faculty of Veterinary Medicine, Zagazig University, Egypt \\ Article History: Received: 30/6/2017 Received in revised form: 30/8/2017 Accepted: 12/9/2017
}

\begin{abstract}
Different sources of Zinc (Zn) were compared to assess their possible effects on performance, nutrients retention, mineral distribution and some serum parameters of broiler chickens. A total of 200 one-day old Ross 308 chicks were divided into in equal four dietary treatments groups with five replicates each of ten chicks. The experimental groups were given the basal diet (inorganic $\mathrm{ZnO}$ ), basal diet supplemented with organic $\mathrm{Zn}$ ( $\mathrm{Zn}$ methionine), nano- $\mathrm{ZnO}$ and $\mathrm{Zn}$ mix (organic $\mathrm{Zn}$ and nano- $\mathrm{ZnO}$ ) at a concentration of $50 \mathrm{mg} / \mathrm{kg}$ of diet. After 42 days of feeding trial, the group supplemented with nano- $\mathrm{ZnO}$ exhibited the best final body weight and feed conversion ratio (2380 g/bird and 1.69 , respectively). Nano- $\mathrm{ZnO}$ and $\mathrm{Zn}$-mix supplementation significantly increased crude fat retention (86.70 and $86.75 \%$, respectively). All sources of supplemented $\mathrm{Zn}$ other than inorganic $\mathrm{ZnO}$ significantly increased $(\mathrm{P}<0.05) \mathrm{Zn}$ retention especially in the group supplemented with nano- $\mathrm{ZnO}$ (41.8\%). Organic $\mathrm{Zn}$ and/or nano-ZnO sources supplemented to broiler diets significantly increased $(\mathrm{P}<0.05)$ iron and copper contents in the hepatic tissue and $\mathrm{Zn}$ content in the tibia. The mean of serum total cholesterol, triglycerides and very low density lipoprotien were significantly reduced $(\mathrm{P}<0.05)$ by dietary supplementation of organic $\mathrm{Zn}$ and/or nano- $\mathrm{ZnO}$. The activity of malondialdehyde was significantly decreased $(\mathrm{P}<0.05)$, while $\mathrm{Cu} / \mathrm{Zn}$ superoxide dismutase activity was significantly increased $(\mathrm{P}<0.05)$ by addition nano-ZnO or $\mathrm{Zn}$-mix. Dietary $\mathrm{Zn}$-mix and nano-ZnO positively affected mRNA expression of insulin like growth factor-1 and growth hormone genes in broilers when compared to the inorganic $\mathrm{ZnO}$ source. The present findings prospected that replacing traditional inorganic $\mathrm{ZnO}$ source with nano- $\mathrm{ZnO}$ or combining nano- $\mathrm{ZnO}$ and $\mathrm{Zn}$ methionine at applied concentration, promoted the growth of broilers, enhanced $\mathrm{Zn}$ up take and antioxidant status without negative effect on selected minerals distribution in tissues.
\end{abstract}

Keywords: Zinc Sources, Performance, Nutrients Retention, Minerals Bio Distribution, Gene Expression, Broilers.

\section{Introduction}

Appropriate trace mineral supplementation is fundamental for several physiological capacities, growth and health of poultry. Zinc $(\mathrm{Zn})$ is an essential trace element required for development and growth of broiler chickens. This essential element has a key part in the structure and maintenance of the skeleton and acts as cofactor in many metabolic processes that necessary for hormone secretion i.e. growth and insulin hormones [1], DNA synthesis, gene expression and cellular division [2], vision photochemistry [3], enhanced the immune status [4] via energy creation, protein synthesis and cell membranes protection from endotoxins producing bacteria [5] gene transcription and RNA synthesis. Also, zinc is vital free radical's scavenger of the in-antioxidant defense system [6]. Traditionally $\mathrm{Zn}$ is supplemented in inorganic forms in poultry diets such as sulfates, oxides and carbonates as they are of low cost. However, in monogastric animals the bioavailability of inoragnic zinc is much low [7]. In the gastrointestinal tract, the inorganic $\mathrm{Zn}$ combined with phytic acid found in most of the broilers grains based diets thus impair zinc and calcium absorption [8], consequently affected the tissue uptake of $\mathrm{Zn}$. Nevertheless, 
the degree of mineral absorption based on the synergism ( $\mathrm{Zn}$ and $\mathrm{Mn}$ ) or antagonism ( $\mathrm{Zn}$ and $\mathrm{Cu})$ of different minerals [9]. In contrast, organic minerals which combined with aminoacids did not interact with phytic acid as they are lacking the free divalent cations needed for chelation in the intestine [10] and thus, they are metabolized in diverse way to facilitate their absorption [11]. Many authors documented that the organic form of dietary zinc for poultry was more bioavailable than its inorganic form, which improved the immunity [12]. On the other hand, with continued genetic modification of commercial broiler strains, the recommended NRC [13] level of $\mathrm{Zn} 40 \mathrm{mg} / \mathrm{kg}$ of diet, is no longer provided sufficient growth, health and reproduction for modern broiler strains. Additionally, increased supplementation of $\mathrm{Zn}$ may influence other trace elements balance and reduced other nutrient stability and long-term exposure that can cause $\mathrm{Zn}$ deposit inside the animal body [6]. The inorganic trace minerals may be replaced by organic sources to reduce the over supplementation and decrease their excretion [14]. The supplementation of organic $\mathrm{Zn}$ in broiler diets is restricted until now due to its relatively high cost. Thus, to get better $\mathrm{Zn}$ bioavailability, other approaches should be considered.

The application of nanotechnology gives rise to nano-sized particles from $\mathrm{Zn}$ called nano $\mathrm{Zn}$ which can replace other zinc forms. As their large surface area, their absorption, utilization and chemical constancy have increased in animal body [15]. The nanoparticles from zinc oxide are most widely used due to its unique physical and chemical properties, easy preparation and environmental-friendless [16]. Supplementation of nano-Zn to broilers exhibited better results on bioavailability when compared with other $\mathrm{Zn}$ sources and also be less toxic for broilers [17]. In addition, Zinc also has a prominent role on many physiological processes that influence signal transduction, gene transcription and RNA synthesis [18]. Yu et al [19] cleared that zinc availability can affect IGF-I gene transcription. Accordingly, this study was designed to evaluate the effects of different dietary $\mathrm{Zn}$ sources or combining nano- $\mathrm{ZnO}$ and organic $\mathrm{Zn}$ on growth performance, nutrient retention, mineral biodistribution $(\mathrm{Zn}, \mathrm{Fe}, \mathrm{Cu}, \mathrm{Mn})$ in different tissues (liver, kidney, muscle and bone) and metabolism of broiler chickens.

\section{Material and Methods}

\section{Experimental birds and management}

All the experimental procedures were approved by the local experimental animal care committee and in accordance with the institutional ethics committee.

A total of 200 one-day old unsexed broiler chicks (Ross 308) obtained from a local hatchery were used. The chicks were weighed on arrival and randomly distributed in equal four groups with five replicates each of ten chicks. Birds were reared under hygienic condition at a density of $10 \mathrm{birds} / \mathrm{m}^{2}$. The temperature was maintained at $33 \pm 1^{\circ} \mathrm{C}$ then decreased gradually $2^{\circ} \mathrm{C}$ each week until reach $21 \pm 1^{\circ} \mathrm{C}$ at the $6^{\text {th }}$ week. The relative humidity during the experimental rearing ranged from 67 to $77 \%$. All birds were vaccinated with Hitchner $B_{1}\left(1^{\text {st }}\right.$ day/eye drop), Coccivac-B $\left(2^{\text {nd }}\right.$ day/eye drops) against Eimeria acervulina, E.mivati, E. maxima, E. tenella live oocysts, Avian influenza (H5N1, 7 days/S/C injection), Gumboro 78 (11 days/eye drop), Lasota (17 days/drinking water) and Gumboro 78 (22 days /drinking water).

\section{Experimental diets and design}

The experimental diet was formulated to Ross 308 broiler nutrition specification (Table 1). The birds were reared for 42 days and the feeding period was divided to starter and finisher period. The diet was not supplemented with phytase. The proximate analysis of the feed ingredients was carried out according to the standard procedures of the AOAC [20]. Four dietary treatment groups were designed as the following: control (inorganic zinc oxide, $\mathrm{ZnO}$, sigma Aldrich), organic- $\mathrm{Zn} \quad(\mathrm{Zn}$ methionine, Zinpro products), nano- $\mathrm{ZnO}$ and $\mathrm{Zn}$-mix groups. The level of Zinc was 50 $\mathrm{mg} / \mathrm{kg}$ diet in control with inorganic $\mathrm{Zn}$, organic- $\mathrm{Zn}$ and nano- $\mathrm{ZnO}$ groups, while the Zn-mix group was contained $25 \mathrm{mg} / \mathrm{kg}$ diet from organic $\mathrm{Zn}$ and $25 \mathrm{mg} / \mathrm{kg}$ from nano$\mathrm{ZnO}$.

\section{Zinc oxide nanoparticles (ZnO NPs)}

The ZnO NPs were purchased from Faculty of Science of Beni Suef University which was 
a white powder with a measured $\mathrm{ZnO}$ NPs content of purity $\geq 99.99 \%$ and size of nanoparticles was $27 \mathrm{~nm}$. The phase characterization of nanoparticles was performed by means of X-ray diffraction (XRD) (Figure 1) using EMPYREAN diffractometer. The morphologies and particle sizes of the Zinc Oxide $(\mathrm{ZnO})$ samples were characterized by JEM- 200CX transmission electron microscopy (TEM) working at $30 \mathrm{kV}$ and Scanning electron microscopy (SEM) images were obtained with a ZIESS EM 902A scanning electron microscope, the characterization of zinc oxide nanoparticles includes: Ref. Code 01-080-7099, Score: 100, Displacement [ $\left.{ }^{\circ} 2 \mathrm{Th}.\right]$ : 0.047, Scale Factor: 1.028

\section{Broiler growth performance and Digestibility trails for estimation of nutrient retention}

Body weight, body weight gain (BWG), feed intake $(\mathrm{FI})$, feed conversion ratio was calculated through the rearing period. At the end of rearing period the allover performance parameters were recorded. Four digestibility trials were conducted. At the end of the growth trial ten birds from each group were randomly selected to carry out the digestibility trail and kept in separate pens and plastic dishes were used for collecting total excreta. Chromic oxide ( $\mathrm{Cr} 2 \mathrm{O} 3)$ was incorporated into the diets of birds in different groups at a rate of $0.3 \%$ as analytical marker [21] for 12 days (seven-days of adaptation period plus five-days for collection of excreta). The collected excreta were dried in hot air oven at $55^{\circ} \mathrm{C}$, ground and stored at $4^{\circ} \mathrm{C}$ until analysis. Digestibility of dry matter, crude protein and crude fat were determined according to AOAC procedures [20].

\section{Zinc analysis in feed and feces}

One gram of excreta was heated for $5 \mathrm{~h}$ in a furnace at $550^{\circ} \mathrm{C}$ for ashing. Ten $\mathrm{mL} 3 \mathrm{~N} \mathrm{HCl}$ was added to the ash sample and heated until the solution became clear. After cooling, filtered and diluted to $50 \mathrm{~mL}$ with $0.1 \mathrm{~N} \mathrm{HCl}$. For zinc analysis, lanthanum 185.4 L 50000 $\mathrm{mg} / \mathrm{kg}$ was added to $6 \mathrm{~mL}$ of the sample solution. Then, analysis was performed using spectrometer with the wavelength set at 400 $\mathrm{nm}[20]$.

\section{Samples collection and serum biochemical parameters}

At the end of the feeding trial, two birds were randomly selected from each replicate and slaughtered and then the blood samples were collected without anticoagulant. The selected tissues samples including, liver, kidney, thigh muscle and bone (tibia) were stored at $-20^{\circ} \mathrm{C}$. The separated serum was used for determining the glucose (GAGO-20, kits from Sigma-Aldrich), total cholesterol (MAK043, kits from Sigma-Aldrich), triglyceride (TAG) (TR0100, kits from SigmaAldrich), high-density lipoprotein (HDL), very low-density lipoprotein (VLDL) (MAK045, kits from Sigma-Aldrich), Malonaldehyde (MDA) (MAK085, kits from Sigma-Aldrich), aspartate aminotransferase (AST) (MAK055, kits from Sigma-Aldrich) and Alanine Amino transferase (ALT) (MAK052, kits from SigmaAldrich) concentration calorimetrically. The activity of $\mathrm{Cu} / \mathrm{Zn}$ superoxide dismutase $(\mathrm{Cu} / \mathrm{Zn}-\mathrm{SOD})$ was determined by OxiSelect ${ }^{\mathrm{TM}}$ ABIN2344995 kits.

\section{Determination of mineral biodistribution}

The mineral concentrations of $\mathrm{Zn}, \mathrm{Fe}$ and $\mathrm{Cu}$ in tissues, including liver, kidney, thigh muscle and bones (tibia) were determined [22]. Briefly, tissues (2 g) were digested in digested tube using an acid mixture $(15 \mathrm{~mL}$ of nitric acid (HNO3), $10 \mathrm{~mL}$ of per-chloric acid $(\mathrm{HClO} 4)$ and $5 \mathrm{~mL}$ of hydrochloric acid $(\mathrm{HCl})$ (HNO3: $\mathrm{HClO} 4: \mathrm{HCl}=3: 2: 1)$. The digest $(25$ $\mathrm{mL}$ ) was with demineralized water. Blanks and standard solutions were prepared. After that, mineral concentrations were determined via an atomic absorption spectrophotometer. 
Table 1: Nutrients composition of starter and grower-finisher basal diet

\begin{tabular}{|c|c|c|}
\hline Ingredients (\%) & Starter diet (day 1-21) & Grower-finisher diet (day 22-42) \\
\hline Corn, ground & 56.6 & 59.6 \\
\hline Soybean meal (48\%) & 32.2 & 26.5 \\
\hline Corn gluten, $60 \%$ & 3.2 & 5.9 \\
\hline Soybean oil & 4 & 4.3 \\
\hline Calcium carbonate & 1.3 & 1.3 \\
\hline Calcium dibasic phosphate & 1.50 & 1.25 \\
\hline Common salt & 0.3 & 0.3 \\
\hline L-Lysine $(78 \%)$ & 0.2 & 0.2 \\
\hline DL-Methionine (98\%) & 0.2 & 0.15 \\
\hline Vitamin premix ${ }^{*}$ & 0.25 & 0.25 \\
\hline Mineral premix ${ }^{* *}$ & 0.25 & 0.25 \\
\hline Total & 100 & 100 \\
\hline \multicolumn{3}{|l|}{ Calculated nutrients ${ }^{* *}$} \\
\hline $\mathrm{ME}(\mathrm{Kcal} / \mathrm{Kg})$ & 3100 & 3200 \\
\hline Protein $(\%)$ & 22.68 & 20.08 \\
\hline $\mathrm{EE}(\%)$ & 6.42 & 6.82 \\
\hline Calcium $(\%)$ & 1.06 & 1.05 \\
\hline Avail. Phos (\%) & 0.47 & 0.44 \\
\hline $\mathrm{Zn}(\mathrm{mg} / \mathrm{kg})$ & 27.31 & 25.46 \\
\hline Lysine $(\%)$ & 1.28 & 1.14 \\
\hline Methionine $(\%)$ & 0.55 & 0.51 \\
\hline
\end{tabular}

\section{Real-time quantitative RT-PCR}

At the end of the experiment, immediately after slaughter liver was dissected and frozen in trizole for assay of growth hormone, insulin- like growth factor-1 genes. Samples were stored at $-20^{\circ} \mathrm{C}$ in a plastic tube for RNA isolation. Total RNA was extracted from tissue samples using Qiagen RNA extraction kits, (Cat, No. 74104). Total RNA purity was determined using NanoDrop_ND-1000 Spectrophotometer. The total RNA was reverse transcribed into cDNA via QIAGEN Long Range 2 Step RT-PCR Kit. One $\mu \mathrm{L}$ of total cDNA was mixed with $12.5 \mu \mathrm{L}$ of $2 \mathrm{x}$ SYBR_Green PCR mix with ROX from Bio$\mathrm{Rad}, 5.5 \mu \mathrm{L}$ of RNAse-free water and $0.5 \mu \mathrm{L}$ of each forward and reverse primers for the measured genes. The up-and downstream primer sequences of growth hormone, insulinlike growth factor- 1 genes were: $\mathrm{GH}$ primers F: 5'- AAC ACA GAT ACC CAA CAG CC3', R: 5'- AGA AGT CAG TGT TTG TCA GGG-3'; IGF-1 primers (F: 5'- CAC CTA AAT CTG CAC GCT-3' and R: CTT GTG
GAT GGC ATG ATC T-3'); $\beta$-actin primers (F: 5'- ACC CCA AAG CCA ACA GA-3' and R: 5'- CCA GAG TCC ATC ACA ATA CC3 '). The $\beta$-actin gene was used as a regulator for normalization [23].

\section{Statistical analyses}

Analysis of variance revealed that the difference between replicates were not significant. The data were analyzed using the General Linear Model procedure, (SPSS, 18 Inc., USA). Difference among treatment means were compared using Duncan's multiple range test. Data were presented as mean $\pm \mathrm{SE}$ and significance was declared at ( $\mathrm{P}$ $<0.05)$.

The statstical model was as the following:

$$
\mathrm{Y}_{\mathrm{ijk}}=\mu+\mathrm{T}_{\mathrm{i}}+\mathrm{R}_{\mathrm{j}}+\mathrm{e}_{\mathrm{ijk}}
$$

Where: $\mu$ is the overall mean for each trait, $T_{i}$ is the fixed effect of diet supplementation $(i=1$, $2, ., 4), R_{j}$ is the fixed effect of replicates $(j=1$, $2, \ldots, 5)$ and $e_{i j k}$ is the random residual effect. 
Table 2: Effects of dietary different forms of $\mathrm{Zn}$ on performance (1-42 days) and nutrient retention of broiler chickens on mineral concentration of selected tissues at 42 days (means \pm standard error)

\begin{tabular}{|c|c|c|c|c|}
\hline \multirow[b]{2}{*}{ Items } & \multicolumn{3}{|c|}{ Dietary groups } & \multirow[b]{2}{*}{ Zn-mix ${ }^{4}$} \\
\hline & Control $^{1}$ & Organic- $\mathbf{Z n}^{2}$ & Nano-ZnO ${ }^{3}$ & \\
\hline \multicolumn{5}{|l|}{ Performance parameters } \\
\hline Body weight (g) & $2018 \pm 19.20^{\mathrm{d}}$ & $2106 \pm 9.54^{\mathrm{c}}$ & $2380 \pm 12.66^{\mathrm{a}}$ & $2302 \pm 4.16^{\mathrm{b}}$ \\
\hline Body weight gain, g/bird & $1972 \pm 32.35^{\mathrm{d}}$ & $2061 \pm 16.86^{\mathrm{c}}$ & $2335 \pm 22.91^{\mathrm{a}}$ & $2256 \pm 7.57^{b}$ \\
\hline Feed intake $(\mathrm{g})$ & $4043 \pm 86.02$ & $3938 \pm 58.59$ & $3954 \pm 83.64$ & $3948 \pm 12.90$ \\
\hline Feed conversion ratio & $2.05 \pm 0.02^{\mathrm{a}}$ & $1.91 \pm 0.02^{\mathrm{b}}$ & $1.69 \pm 0.03^{\mathrm{d}}$ & $1.75 \pm 0.01^{\mathrm{c}}$ \\
\hline Protein efficiency ratio & $2.33 \pm 0.02^{\mathrm{c}}$ & $2.51 \pm 0.02^{\mathrm{b}}$ & $2.83 \pm 0.05^{\mathrm{a}}$ & $2.73 \pm 0.02^{\mathrm{ab}}$ \\
\hline \multicolumn{5}{|l|}{ Nutrient retention $(\%)$} \\
\hline Dry matter & $88.10 \pm 0.05$ & $89.45 \pm 0.02$ & $89.37 \pm 0.03$ & $89.8 \pm 0.05$ \\
\hline Crude protein & $86.92 \pm 0.02$ & $87.20 \pm 0.01$ & $87.65 \pm 0.01$ & $87.32 \pm 0.03$ \\
\hline Crude fat & $85.39 \pm 0.06^{\mathrm{b}}$ & $85.90 \pm 0.02^{\mathrm{b}}$ & $86.70 \pm 0.01^{\mathrm{a}}$ & $86.75 \pm 0.03^{\mathrm{a}}$ \\
\hline Zinc & $30.25 \pm 0.2^{\mathrm{c}}$ & $38.47 \pm 0.08^{\mathrm{b}}$ & $41.8 \pm 0.09^{\mathrm{a}}$ & $40.59 \pm 0.1^{\mathrm{a}}$ \\
\hline \multicolumn{5}{|l|}{ Tissues bio-bistribution } \\
\hline \multicolumn{5}{|l|}{ Liver } \\
\hline $\mathrm{Zn}(\mathrm{mg} / \mathrm{kg})$ & $70.68 \pm 0.06$ & $71.64 \pm 0.04$ & $71.95 \pm 0.02$ & $68.48 \pm 0.02$ \\
\hline $\mathrm{Fe}(\mathrm{mg} / 10 \mathrm{~g})$ & $12.25 \pm 0.09^{\mathrm{b}}$ & $13.9 \pm 0.04^{\mathrm{a}}$ & $15.64 \pm 0.05^{\mathrm{a}}$ & $14.66 \pm 0.04^{\mathrm{a}}$ \\
\hline $\mathrm{Cu}(\mathrm{mg} / \mathrm{kg})$ & $13.21 \pm 0.08^{\mathrm{b}}$ & $14.9 \pm 0.05^{\mathrm{a}}$ & $15.3 \pm 0.05^{\mathrm{a}}$ & $15.54 \pm 0.04^{\mathrm{a}}$ \\
\hline \multicolumn{5}{|l|}{ kidney } \\
\hline Zinc (mg/kg) & $15.24 \pm 0.04$ & $16.31 \pm 0.07$ & $15.98 \pm 0.07$ & $15.9 \pm 0.03$ \\
\hline $\mathrm{Fe}(\mathrm{mg} / \mathrm{kg})$ & $257.36 \pm 0.09$ & $255.87 \pm 0.09$ & $259.9 \pm 0.06$ & $261.58 \pm 0.07$ \\
\hline $\mathrm{Cu}(\mathrm{mg} / \mathrm{kg})$ & $16.64 \pm 0.03$ & $16.2 \pm 0.03$ & $16.80 \pm 0.07$ & $15.97 \pm 0.05$ \\
\hline \multicolumn{5}{|l|}{ Thigh muscle } \\
\hline $\mathrm{Zn}(\mathrm{mg} / \mathrm{kg})$ & $25.31 \pm 0.04$ & $25.00 \pm 0.09$ & $25.6 \pm 0.1$ & $25.2 \pm 0.03$ \\
\hline $\mathrm{Fe}(\mathrm{mg} / \mathrm{kg})$ & $160.25 \pm 0.08$ & $160.2 \pm 0.06$ & $163.2 \pm 0.06$ & $162.3 \pm 0.04$ \\
\hline $\mathrm{Cu}(\mathrm{mg} / \mathrm{kg})$ & $5.5 \pm 0.04$ & $5.92 \pm 0.05$ & $6.1 \pm 0.03$ & $6.1 \pm 0.02$ \\
\hline \multicolumn{5}{|l|}{ Tibia bone } \\
\hline $\mathrm{Zn}(\mathrm{mg} / \mathrm{kg})$ & $250.32 \pm 0.04^{b}$ & $265.3 \pm 0.04^{\mathrm{a}}$ & $265.36 \pm 0.06^{\mathrm{a}}$ & $260.32 \pm 0.04^{\mathrm{a}}$ \\
\hline $\mathrm{Fe}(\mathrm{mg} / \mathrm{kg})$ & $12.50 \pm 0.06$ & $13.34 \pm 0.01$ & $13.61 \pm 0.03$ & $14.10 \pm 0.02$ \\
\hline $\mathrm{Cu}(\mathrm{mg} / \mathrm{kg})$ & $11.10 \pm 0.09$ & $11.50 \pm 0.1$ & $12.54 \pm 0.04$ & $12.35 \pm 0.08$ \\
\hline
\end{tabular}

\section{Results and Discussion}

\section{Performance parameters}

Zinc is practically added to all formulated broiler diets to support their development and growth. As the inorganic source of $\mathrm{Zn}$ has low bioavailability especially when incorporated with grain based diet, it is an urgent need to increase their dietary level than recommended by the NRC. However, this can lead to higher $\mathrm{Zn}$ excretion and environmental pollution. From this point, our dietary strategy has been directed for applying other sources of supplemental $\mathrm{Zn}$ with higher bioavailability in broiler diets as organic $\mathrm{Zn}$ and the most recently available nano-Zn. The effects of different dietary sources of $\mathrm{Zn}$ on performance parameters of broiler chickens are shown in Table (2). The data of broiler performance (142 days) were significantly affected by different supplemental Zn sources except for feed consumption. The broilers group received nano-ZnO had significantly $(\mathrm{P}<0.05)$ higher body weight gain, better feed conversion and protein utilization followed by the group supplemented with Zn-mix (oraganic and nano- $\mathrm{ZnO})$ and finally organic $\mathrm{Zn}$ ( $\mathrm{Zn}$ methionine) supplemented group when compared with the traditionally inorganic $\mathrm{ZnO}$ 
supplemented diet. Replacing inorganic $\mathrm{ZnO}$ with nano- $\mathrm{ZnO}$ source, $\mathrm{Zn}$-mix and $\mathrm{Zn}$ methionine caused an increase in weight gain at the end of the rearing period (approximately 15.5, 12.5 and $4.3 \%$, respectively). These Results showed that using of supplemental organic and/or nano-Zn promoted growth performance of broilers. The nanoparticles can efficiently satisfy the mineral requirement by animals, enhanced their production performance and feed efficiency [24]. Its application in animal feeding with low level, can be substituted to antibiotic growth promoters and diminish the environmental pollution [25]. In accordance with these findings Zhao et al., [6] demonstrated that feeding of broilers on nano- $\mathrm{ZnO}$ (20 or 60 $\mathrm{mg} / \mathrm{kg}$ ) were improved the feed conversion and growth rate than feeding organic $\mathrm{Zn}$. In addition, dietary supplementation of nano- $\mathrm{Zn}$ in combination with an organic $\mathrm{Zn}$ source $(80$ $\mathrm{mg} / \mathrm{kg}$ ) enhanced the growth performance of broiler chickens than when dietary nano-Zn supplemented with inorganic $\mathrm{Zn}$ source with the same level [26]. Also, the growth performance of broilers was improved due to higher bioavailability of supplemented organic $\mathrm{Zn}$ sources [27] and the positive properties of $\mathrm{Zn}$ methionine on nutrients digestion and absorption. Also, if $\mathrm{Zn}$ methionine did not modify during absorption and transportation, its supply for tissues will increase and thus improves animal productivity [28]. These positive effects were more prominent with nano $-\mathrm{Zn}$ than organic $\mathrm{Zn}$ due to the higher bioavailability of nanoparticles.

The development of indigestible complexes between minerals and other dietary ingredients may be prevented by addition of organic trace minerals as well as it can also decrease antagonism between minerals [29], thus will affect the broilers growth rate. The current results of feed consumption agreed with Puchala et al. [30] who reported that adding of graded levels of organic Zn (15, 30, 45 and 60 $\mathrm{ppm} / \mathrm{kg}$ diet) to broiler chickens did not significantly affect their feed intake when compared with the inorganic $\mathrm{Zn}$.

Table 3: Effects of dietary different forms of zinc on serum parameters of broiler chickens (means \pm standard error)

\begin{tabular}{|c|c|c|c|c|}
\hline \multicolumn{5}{|c|}{ Dietary groups } \\
\hline Parameters & Control $^{1}$ & Organic- $\mathbf{Z n}^{2}$ & Nano- $\mathrm{ZnO}^{3}$ & Zn-mix ${ }^{4}$ \\
\hline Glucose (mg/dL) & $242.30 \pm 0.07$ & $240.24 \pm 0.05$ & $245.26 \pm 0.02$ & $247.50 \pm 0.06$ \\
\hline Total cholesterol (mg/dL) & $165.25 \pm 0.08^{\mathrm{a}}$ & $158.36 \pm 0.2^{\mathrm{b}}$ & $155.34 \pm 0.09^{b}$ & $147.32 \pm 0.1^{\mathrm{c}}$ \\
\hline TAG $^{5}(\mathrm{mg} / \mathrm{dL})$ & $276.23 \pm 0.05^{\mathrm{a}}$ & $198.32 \pm 0.08^{b}$ & $180.5 \pm 0.08^{c}$ & $188.25 \pm 0.05^{\mathrm{bc}}$ \\
\hline HDL-C ${ }^{6}(\mathrm{mg} / \mathrm{dL})$ & $46.94 \pm 0.01^{\mathrm{b}}$ & $47.55 \pm 0.03^{\mathrm{a}}$ & $47.65 \pm 0.04^{\mathrm{a}}$ & $47.21 \pm 0.04^{\mathrm{a}}$ \\
\hline VLDL-C ${ }^{7}$ (mg/dL) & $55.25 \pm 0.08^{c}$ & $39.66 \pm 0.06^{b}$ & $36.1 \pm 0.09^{\mathrm{a}}$ & $37.55 \pm 0.09^{\mathrm{ab}}$ \\
\hline $\operatorname{AST}^{8}(\mathrm{mg} / \mathrm{dL})$ & $176.99 \pm 0.02$ & $175.61 \pm 0.07$ & $179.65 \pm 0.01$ & $178.32 \pm 0.06$ \\
\hline $\operatorname{ALT}^{9}(\mathrm{mg} / \mathrm{dL})$ & $53.32 \pm 0.04$ & $53.20 \pm 0.08$ & $56.3 \pm 0.06$ & $54.32 \pm 0.06$ \\
\hline $\operatorname{MDA}^{10}(\mathbf{n m o L} / \mathbf{m L})$ & $2.63 \pm 0.08^{\mathrm{a}}$ & $2.46 \mathrm{~b} \pm 0.04^{\mathrm{b}}$ & $2.30 \pm 0.1^{b}$ & $2.42 \pm 0.3^{c}$ \\
\hline CuZn-SOD ${ }^{11}(\mathrm{U} / \mathrm{mgp})$ & $238.22 \pm 0.09^{c}$ & $247.25 \pm 0.1^{\mathrm{b}}$ & $255.36 \pm 0.09^{\mathrm{a}}$ & $247.40 \pm 0.2^{\mathrm{ab}}$ \\
\hline
\end{tabular}

${ }^{1}$ Control: group supplemented with inorganic zinc oxide; ${ }^{2}$ Organic-Zn: group supplemented with $\mathrm{Zn}$ methionine; ${ }^{3}$ Nano-ZnO: group supplemented with nano $\mathrm{Zn}$-oxide; ${ }^{4} \mathrm{Zn}$-mix: group supplemented with both $\mathrm{Zn}$ methionine and nano Zn-oxide; ${ }^{5}$ TAG: Triglyceride; ${ }^{6} \mathrm{HDL}-\mathrm{C}$ : High-density lipoprotein; ${ }^{7}$ VLDL-C: Very low-density lipoprotein; ${ }^{8} \mathrm{AST}$ : Aspartate amino transferase; ${ }^{9} \mathrm{ALT}$ : Alanine amino transferase; ${ }^{10} \mathrm{MDA}$ : Malondialdehyde; ${ }^{11} \mathrm{CuZn}-\mathrm{SOD}$ : $\mathrm{Cu} / \mathrm{Zn}$ superoxide dismutase. ${ }^{\mathrm{a}-\mathrm{b}-\mathrm{c}}$ Means in a row with different superscripts were significantly different $(\mathrm{P}<0.05)$.

\section{Nutrient retention}

Dietary supplementation of different zinc sources on nutrient retention of broilers are shown in table 2. Dry matter, crude protein retention were not affected by different zinc supplementation $(\mathrm{P}>0.05)$, while the retention of crude fat and zinc were affected. Fat retention was higher in nano-Zn and mix- $\mathrm{Zn}$ groups than that in organic $\mathrm{Zn}$ and the control group $(\mathrm{P}<0.05)$. The addition of organic $\mathrm{Zn}$ and/or nano-Zn to broiler diets significantly increased $(\mathrm{P}<0.05) \mathrm{Zn}$ retention in the body when compared with the control group. The 
same results were obtained by Tsai et al. [1] who stated that feeding of laying hens on dietary inorganic, organic and nano- $\mathrm{Zn}$ had no significant affect in nutrient retention, although $\mathrm{Zn}$ retention was significantly increased in groups supplemented with organic and nano- $\mathrm{Zn}$ when compred with inorganic $\mathrm{Zn}$ group. As the inorganic trace minerals dissociate in the upper gastrointestinal tract due to the low $\mathrm{pH}$, thus these separated minerals can antagonize other minerals or combined with other dietary components in the digesta and hinder their absorption in the small intestine [31]. In addition, Zn-methionine supplementation in broiler chickens had higher bioavailability than inorganic $\mathrm{Zn}$ which absorbed through amino acid transport systems, resulting in higher bioavailability [32]. High concentrations of $\mathrm{Zn}$ in poultry excreta due to their lower bioavailability cause environmental pollution and soil phytotoxicity when these excreta used as fertilizers and the high bioavailability of organic and nano- $\mathrm{Zn}$ will decrease $\mathrm{Zn}$ excretion [33]. Similarly, several studies reported that supplementation of organic minerals for broiler diets can improve the mineral uptake, enhance gain and reduce the excretion of minerals [34,35]. Nanoparticles revealed unique physical characteristics of transport and uptake that display higher absorption efficiencies when compared with the inorganic and organic $\mathrm{Zn}$ sources [36]. The current results concluded that the supplementation of required level of organic and/or nano-Zn minerals lead to higher mineral retention with higher bioavailability. Additionally, the results related to fat retention are in harmony with Tronina et al. [37] who reported that dietary Zn-Gly (organic source) could increase body fat content of broilers. The intramuscular fat of the broiler breast meat fed diets supplemented with $\mathrm{Zn}$ was higher than the control [38] which may be attributed to that the dietary $\mathrm{Zn}$ can influence fat metabolism in liver and enhance the lipid synthesis for broilers by controlling the activities and gene expressions of lipogenic enzymes [39].

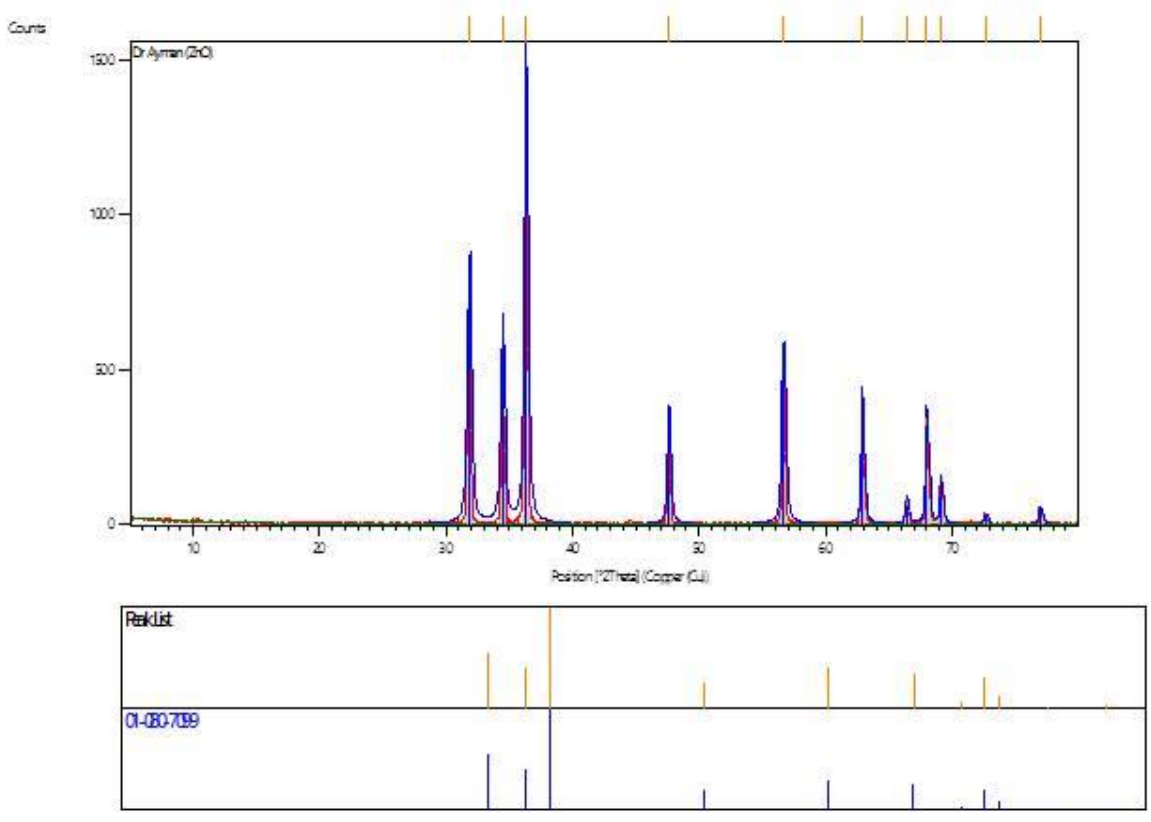

Figure 1. X-ray Diffraction of zinc oxide nano particles 


\section{Mineral contents of selected tissues}

The influence of different $\mathrm{Zn}$ sources in tissues mineral contents is shown in table 2 . There was no significant difference in $\mathrm{Zn}$ contents of the selected tissues except for tibia, where the highest $\mathrm{Zn}$ concentration was estimated in groups supplemented with organic $\mathrm{Zn}$ and /or nano-ZnO compared to the control group. Supplementation of organic $\mathrm{Zn}$ and/or nano-ZnO had no significant effect on $\mathrm{Fe}$ and $\mathrm{Cu}$ contents in the kidney, thigh muscle and tibia, while hepatic $\mathrm{Fe}$ and $\mathrm{Cu}$ contents were significantly increased $(\mathrm{P}<0.05)$ in the groups fed diets supplemented with organic $\mathrm{Zn}$ and/or nano-ZnO. Thus, introducing the organic or nano-Zn trace elements into animal nutrition could alter mineral deposition in tissues due to their proper bioavailability when compared with the inorganic sources. The ability of nano minerals to pass through the small intestine and distribute in the body are much greater than inorganic and organic minerals [40]. Tissue mineral biodistribution can be used as an index of mineral storages in the body [41]. In the same line, Sunder et al. [42] reported that the addition of organic $\mathrm{Zn}$ to broilers $(80 \mathrm{ppm} / \mathrm{kg}$ diet $)$ lead to higher minerals precipitation ( $\mathrm{Zn}$ and $\mathrm{Mn}$ ) in the bone. Also, Mwangi et al. [43] specified that increasing dietary $\mathrm{Zn}$ and Mn supplementation were desired for a higher mineral storage in the liver. Ivanišinová, et al. [44] reported that higher bioavailability of organic $\mathrm{Zn}$ associated with its higher concentration in the hepatic tissues. It was described that zinc influenced the absorption and biodistribution of $\mathrm{Cu}, \mathrm{Fe}$ and $\mathrm{Mn}$ trace minerals [45]. It appears from our results that the organic and/or nano- $\mathrm{Zn}$ content in broilers diets did not affect the mineral distribution in tissues except for the liver. Ao et al. [46] reported that there is an antagonism between $\mathrm{Zn}$ and $\mathrm{Cu}$ when the inorganic sources used, while this antagonism was not existed when organic sources of minerals were incorporated in broiler diet. Nevertheless, feeding of mice on dietary nano$\mathrm{Zn}$ oxide by the level of $(50,500$ and 5000 $\mathrm{mg} / \mathrm{kg}$ ) had no significant effect on the $\mathrm{Cu}, \mathrm{Fe}$, and Mn content in the kidney, thigh and testis and significantly affect on the hepatic $\mathrm{Fe}$ content and pancreas Mn level [47]. Tibia zinc concentration in nanoparticle zinc samples from broiler chickens was significantly higher relative to the control and zinc-sulphate groups [48].

\section{Serum parameters}

The serum biochemical parameters in relation to different dietary sources of $\mathrm{Zn}$ are shown in Table (3). There was no significant difference in glucose levels among different treated groups. The results indicated that the serum total cholesterol, triglyceride and very low-density lipoprotein were significantly decreased $(\mathrm{P}<0.05)$ in groups supplemented with organic $\mathrm{Zn}$ and/or nano $\mathrm{Zn}$, while the lowest values were observed in broilers group fed on nano $\mathrm{Zn}$. The high density lipoprotein was not affected by organic $\mathrm{Zn}$ and/or nano $\mathrm{Zn}$ supplementation. Serum malondialdehyde (MDA) level was significantly decreased ( $\mathrm{P}<$ $0.05)$ while the $\mathrm{Cu} / \mathrm{Zn}$ superoxide dismutase $(\mathrm{Cu} / \mathrm{Zn}-\mathrm{SOD})$ level was significantly increased $(\mathrm{P}<0.05)$ with dietary organic $\mathrm{Zn}$ and/or nano $\mathrm{ZnO}$, which indicated that the addition of organic $\mathrm{Zn}$ and/or nano $\mathrm{Zn}$ enhanced the antioxidant activity of broilers. The hepatic activities of aspartate amino transferase and alanine amino transferase were not significantly affected by the different dietary sources of Zn. Zinc has an important role in scavenging of free radicals and reactive oxygen species and considered as an essential element in the formation and function of $\mathrm{Cu}$ $\mathrm{Zn}$ superoxide dismutase [6]. One of the most important antioxidant functions of $\mathrm{Zn}$ is related to elevation of $\mathrm{Cu} / \mathrm{Zn} \mathrm{SOD}$ activity in chicken liver [48]. The results of our study indicate that organic zinc and/or nano $\mathrm{Zn}$ sources had a similar effect on the activity of $\mathrm{Cu} / \mathrm{Zn}$ SOD in tissues. In the same line, Fathi et al. [49] revealed that serum concentrations of MDA in broiler chickens was significantly $(\mathrm{P}<0.05)$ decreased at $20 \mathrm{mg} / \mathrm{kg}$ nano- $\mathrm{ZnO}$. ZONPs associated with reduction of serum low density lipoproteins, triglyceride and cholesterol, besides increased high density lipoproteins compared to the control treatment [50]. This can be attributed to reduction of the absorption of dietary lipids and decline in caloric intake [51]. Also, Berg and Shi [52] reported that there was a contrary connection between zinc oxide nanoparticles and serum MDA concentration. Supplementation of nano-Zn to broiler diets $(0.06 \mathrm{mg} / \mathrm{kg})$ 
accompanied by decreasing the blood cholesterol level and improving the bird's immunity when compared with organic and inorganic $\mathrm{Zn}$ sources [17]. The alteration of blood cholesterol levels may be linked to the zinc's role in enzymes systems (metalloenzymes) which plays a vital role in fat metaboilsm [53]. Ahmadi et al. [50] reported that the dietary nano- $\mathrm{ZnO}$ had no significant role in aspartate amino transferase and alanine amino transferase activities in serum of broilers.
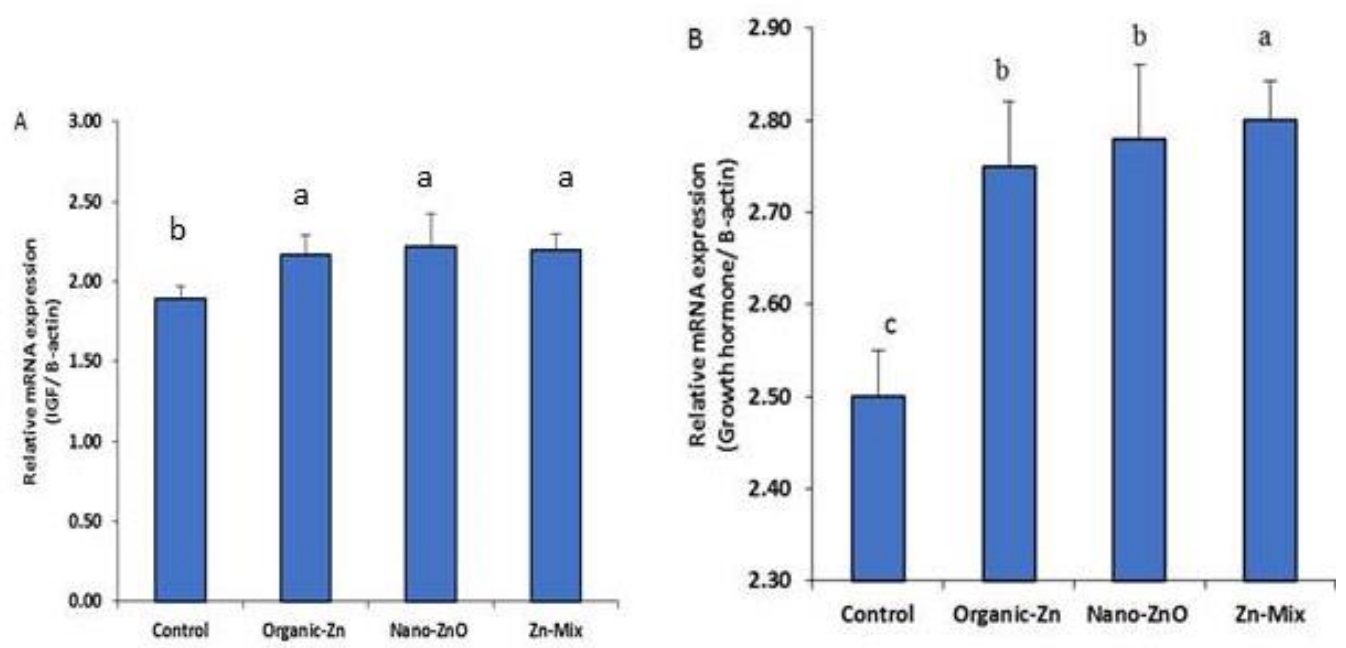

Figure 2: Effect of different dietary forms of zinc on the relative mRNA expression of A) insulin like growth factor-1 and B) growth hormone genes of broilers chicken. Control = group supplemented with inorganic zinc oxide, Organic- $\mathrm{Zn}=$ group supplemented with $\mathrm{Zn}$ methionine, Nano- $\mathrm{ZnO}=$ group supplemented with nano $\mathrm{Zn}$-oxide and $\mathrm{Zn}$-mix = group supplemented with both $\mathrm{Zn}$ methionine and nano $\mathrm{Zn}$-oxide.

\section{Insulin like growth factor-1 and growth hormone genes expression}

Data regarding the gene expression are presented in Figure (2). The present results showed that supplementation of broiler diets with organic $\mathrm{Zn}$ and/or nano $\mathrm{ZnO}$ significantly increased $(\mathrm{p}<0.05)$ mRNA expression of insulin like growth factor gene (IGF-I). Moreover, the mRNA expression of IGF-I gene tended to be increased in nano- $\mathrm{ZnO}$ supplemented group than in $\mathrm{Zn}$-mix and organic groups. Compared to inorganic $\mathrm{ZnO}$, addition of nano-ZnO and $\mathrm{Zn}$-mix significantly increased $(\mathrm{p}<0.05)$ mRNA expression of growth hormone followed by the group supplemented with $\mathrm{Zn}$ methionine. The high bioavailability of organic $\mathrm{Zn}$ and nano$\mathrm{ZnO}$ indicates that more $\mathrm{Zn}$ was taken through the body and not only deposited in bone compared with inorganic $\mathrm{ZnO}$, thus affected cellular function responsible for hormones and growth factor secretions. Similarly, Zn augmented the growth factor synthesis, as IGF-1 and influenced the action of calciumregulating hormones [54]. Also, Zn plays an important role in the formation of insulin through its enzyme systems [7]. Compared with inorganic $\mathrm{Zn}$ supplemented group, the serum level of IGF-1 was increased in the organic-Zn group [55]. Other results in mice, showed that dietary $\mathrm{Zn}$ - methionine increased the body weight gain and up-regulated mRNA expression of IGF-I more than dietary inorganic $\mathrm{Zn}$ [56].

\section{Conclusion}

The present study suggested that supplementation of nano- $\mathrm{ZnO}$ or even combing organic $\mathrm{Zn}$ and nano- $\mathrm{ZnO}$ with a dose of $50 \mathrm{mg} / \mathrm{kg}$ diet have positive effects on broiler performance, $\mathrm{Zn}$ retention and enhanced their antioxidant activity. In addition, the trace mineral contents of selected tissues in relation to dietary treatment not affected except for $\mathrm{Fe}$ and $\mathrm{Cu}$, which increased in hepatic tissues. Also, supplemental nano$\mathrm{ZnO}$ or combination organic $\mathrm{Zn}$ and nano- $\mathrm{ZnO}$ improved the broiler's metabolism by increased the activities of insulin like growth factor and growth hormone genes. 


\section{Conflict of interest}

The authors declare no conflict of interest.

\section{References}

[1] Tsai, Y.H.; Mao, S.Y.; Li, M.Z.; Huang, J.T. and Lien, T.F. (2016): Effects of nanosize zinc oxide on zinc retention, eggshell quality, immune response and serum parameters of aged laying hens. Anim Feed Sci Technol, 213: 99-107.

[2] Prasad, A.S. (1991): Discovery of human zinc deficiency and studies in an experimental human model. Am J Clin Nutr, 53 (2):403-412.

[3] Suchý, P.; Suchý, P.J.R. and Strakova, E. (1998): Micro-elements in nutrition of farm animals. Krmiva and Výživa, 3-4.

[4] Parashuramulu, S.; Nagalakshmi, D.; Rao, D.S.; Kumar, M.K. and Swain, P.S. (2015): Effect of zinc supplementation on anti-oxidant status and immune response in buffalo calves. Anim Nutr Feed Technol, 15 (2):179-88.

[5] Nockels, C.F. (1994): Micornutrients and the immune response. In: Montana nutrition Conference Proceedings, Bozeman, Montana, 3.1; 1994.

[6] Zhao, C.Y.; Tan, S.X.; Xiao, X.Y.; Qiu, Z.S.; Pan, J.O. and Tang, Z.X. (2014): Effects of dietary zinc oxide nanoparticles on growth performance and antioxidative status in broilers. Biol Trace Elem Res, 160(3): 361-367.

[7] Brody, T. (1994): Nutritional Biochemistry. Academic press, New York, 581-591.

[8] McDowell, L.R. (2003): Minerals in Animal and Human Nutrition. Academic Press Inc, New York, 265-292.

[9] Gajula, S. S.; Chelasani, V. K.; Panda, A. K.; Mantena, V. R. and Savaram, R. R. (2011): Effect of supplemental inorganic $\mathrm{Zn}$ and $\mathrm{Mn}$ and their interactions on the performance of broiler chicken, mineral bioavailability and immune response. Biol Trace Elem Res, 139(2): 177-187.

[10] Kidd, M.T.; Ferket, P.R. and Qureshi, M.A. (1996): Zinc metabolism with special reference to its role in immunity. World Poult Sci J, 52(3): 309-324.

[11] Burrell, A.L.; Dozier, W.A.; Davis, A.J.; Compton, M.M.; Freeman, M.E.; Vendrell, P.F.; and Ward, T.L. (2004): Responses of broilers to dietary zinc concentrations and sources in relation to environmental implications. Br poult Sci, 45(2): 255-263.

[12] Ao, T.; Pierce, J.L.; Power, R.; Dawson, K.A.; Pescatore, A.J.; Cantor, A.H. and Ford, M. J. (2006): Evaluation of Bioplex $\mathrm{Zn}$ as an organic zinc source for chicks. Int J Poult Sci, 5 (9): 808-811.

[13] National Research Council (NRC). (1994): Nutrition Requirements of poultry. 9th Ed., Washington, DC National Academy Press.

[14] Nollet, L.; Huyghebaert, G. and Spring, P. (2008): Effect of different levels of dietary organic (bioplex) trace minerals on live performance of broiler chickens by growth phases. J Appl Poult Res, 17(1): 109-115.

[15] Rajendran. D.; Kumar, G.; Ramakrishnan, S. and Thomas, K.S. (2013): Enhancing the milk production and immunity in Holstein Friesian crossbred cow by supplementing novel nano zinc oxide. Res J Biotechnol, 8(5):11-17.

[16] Wahab, R.; Dwivedi, S.; Umar, A.; Singh, S.; Hwang, I.H.; Shin, H.S.; Musarrat, J.; Al-Khedhairy, A.A. and Kim, Y.S. (2013) ZnO nanoparticles induce oxidative stress in Cloudman S91 melanoma cancer cells. J Biomed Nanotechnol, 9(13):441-449.

[17] Sahoo, A.; Swain, R.K. and Mishra, S.K. (2014): Effect of inorganic, organic and nano zinc supplemented diets on bioavailability and immunity status of broilers. Int J Adv Res, 2 (11):828-837.

[18] MacDonald RS. The role of zinc in growth and cell proliferation (2000): Journal of Nutrition, 130: 1500-1508.

[19] Yu, Z.P.; Le, G.W. and Shi, Y.H., (2005): Effect of zinc sulphate and zinc methionine on growth, Plasma growth 
hormone concentration, growth hormone receptor and insulin-like growth factor-I gene expression in mice. Clinical and Experimental Pharmacology and Physiology. 32(4): 273-278.

[20] AOAC. (2002): Official Methods of Analysis. 17th Edn. Association of Official Analytical Chemists, Arlington, VA.

[21] Friesen, O. D.; Guenter, W.; Marquardt, R. R. and Rotter, B. A. (1992): The effect of enzyme on the apparent ME and nutrient digestibility of wheat, barley, oats and rye for the young broiler chick. Poult Sci, 71(10): 1710-1721.

[22] Demirbaş, A. (1999): Proximate and heavy metal composition in chicken meat and tissues. Food Chem, 67(1): 27-31.

[23] Del Vesco, A.P.; Gasparino, E.; Oliveira Neto, A.R.; Guimarães, S.E.F.; Marcato S.M.M. and Voltolini, D.M. (2013): Dietary methionine effects on IGF-Iand GHR mRNA expression in broilers. Genet Mol Res, 12(4): 6414-6423.

[24] Oberdörster, G.; Oberdörster, E. and Oberdörster, J. (2005): Nanotoxicology: an emerging discipline evolving from studies of ultrafine particles. Environ Health Perspect, 113(7): 823-839.

[25] Schmidt, C.W. (2009): Nanotechnologyrelated environment, health, and safety research: examining the national strategy. Environ Health Perspect, 117 (4), 158-161.

[26] Mohammadi, V.; Ghazanfari, S.; Mohammadi-Sangcheshmeh, A. and Nazaran, M.H. (2015): Comparative effects of zinc-nano complexes, zincsulphate and zinc-methionine on performance in broiler chickens. Br Poult Sci, 56 (4):486-493.

[27] Feng, J.W.Q.M.; Ma, W.Q.; Niu, H.H.; Wu, X.M. and Wang, Y. (2010): Effects of zinc glycine chelate on growth, hematological, and immunological characteristics in broilers. Biol Trace Elem Res, 133 (2):203-211.

[28] Świątkiewicz, S.; Arczewska-Włosek, A. and Jozefiak, D. (2014): The efficacy of organic minerals in poultry nutrition: review and implications of recent studies. World Poult Sci J, 70(3):475486.

[29] Rossi, P.; Rutz, F.; Anciuti, M.A. Rech, J.L. and Zauk, N.H.F. (2007): Influence of graded levels of organic zinc on growth performance and carcass traits of broilers. J Appl Poult Res, 16(2):219225.

[30] Puchala, R.; Sahlu, T. and Davis, J.J. (1999): Effects of zinc-methionine on performance of Angora goats. Small Rumin Res, 33(1):1-8.

[31] Yan, F. and Waldroup, P. W. (2006): Evaluation of Mintrex ${ }^{\circledR}$ manganese as a source of manganese for young broilers. Int J Poult Sci, 5 (8): 708-713.

[32] Star, L.; van der Klis, J.D.; Rapp, C. and Ward, T.L. (2012) Bioavailability of organic and inorganic zinc sources in male broilers. Poult Sci, 91(12): 31153120 .

[33] Kibet, L. C.; Allen, A. L.; Church, C.; Kleinman, P. J. A.; Feyereisen G. W.; Saporito L. S., Hashem, F.; May, E. B. and Way, T. R. (2013): Transport of dissolved trace elements in surface runoff and leachate from a coastal plain soil after poultry litter application. Journal of Soil and Water Conservation, 68(3): $212-220$

[34] Sahraei, M.; Janmmohamadi, H.; Taghizadeh, A.; Moghadam, G.A. and Rafat, S.A. (2013): Estimation of the relative bioavailability of several zinc sources for broilers fed a conventional corn-soybean meal diet. Poult Sci, 50(1): 53-59

[35] Yenice, E., Mızrak, C.; Gültekin, M., Atik, Z. and Tunca, M. (2015): Effects of organic and inorganic forms of manganese, zinc, copper, and chromium on bioavailability of these minerals and calcium in late-phase laying hens. Biol Trace Elem Res, 167(2): 300-307

[36] Liao, C. D.; Hung, W. L.; Jan, K. C.; Yeh, A. I.; Ho, C. T. and Hwang, L. S. (2010): Nano/sub-microsized lignan glycosides from sesame meal exhibit 
higher transport and absorption efficiency in Caco-2 cell monolayer. Food Chem, 119(3): 896-902.

[37] Tronina, W., Kinal, S. and Lubojemska, B. (2007): Effect of various forms of zinc applied in concentrate mixtures for broiler chickens on its bioavailability as well as meat composition and quality. Polish J Food Nutr Sci, 57(Suppl. 4C):577-581.

[38] Liu, Z.H.; Lu, L., Li, S.F.; Zhang, L.Y., Xi, L., Zhang, K.Y. and Luo, X.G. (2011): Effects of supplemental zinc source and level on growth performance, carcass traits, and meat quality of broilers 1. Poult Sci, 90(8):1782-1790.

[39] Liu, Z. H.; Lu, L.; Wang, R. L.; Lei, H. L.; Li, S. F.; Zhang L. Y. and Luo X. G. (2015): Effects of supplemental zinc source and level on antioxidant ability and fat metabolism-related enzymes of broilers. Poult Sci, 94 :2686-2694.

[40] Hillyer, J.F. and Albrecht, R.M. (2001): Gastrointestinal persorption and tissue distribution of differently sized colloidal gold nanoparticles. JPharm Sci, 90(12):1927-1936.

[41] Wedekind, K. J.; Hortin A. E. and Baker D. H. (1992): Methodology for assessing zinc bioavailability: Efficacy estimates for zinc-methionine, zinc sulfate, and zinc oxide. J Anim Sci, 70(1):178-187

[42] Sunder, G. S.; Kumar, C. V.; Panda, A. K.; Raju, M. V. L. N. and Rama Rao, S. V. (2013): Effect of supplemental organic $\mathrm{Zn}$ and $\mathrm{Mn}$ on broiler performance, bone measures, tissue mineral uptake and immune response at 35 days of age. Curr Res Poult Sci, 3(1):1-11.

[43] Mwangi, S.; Timmons, J.; Ao, T.; Paul, M.; Macalintal, L.Ç.; Pescatore, A., Cantor, A.; Ford, M. and Dawson, K.A. (2017): Effect of zinc imprinting and replacing inorganic zinc with organic zinc on early performance of broiler chicks. Poult Sci, 96(4):861-868.

[44] Ivanišinová, O.; Grešáková, L'; Ryzner, M.; Ocel'ová, V. and Čobanová, K. (2016): Effects of feed supplementation with various zinc sources on mineral concentration and selected antioxidant indices in tissues and plasma of broiler chickens. Acta Veterinaria Brno, 85(3): 285-291.

[45] Willis, M.S., Monaghan, S.A.; Miller, M.L.; McKenna, R.W.; Perkins, W.D.; Levinson, B.S.; Bhushan, V. and Kroft, S.H. (2005): Zinc-induced copper deficiency: a report of three cases initially recognized on bone marrow examination Am J Clin Pathol, 123(1): 125-131.

[46] Ao, T.; Pierce, J.L.; Power, R.; Pescatore, A.J.; Cantor, A.H.; Dawson, K.A. and Ford, M.J. (2009): Effects of feeding different forms of zinc and copper on the performance and tissue mineral content of chicks. Poult Sci, 88(10): 2171-2175.

[47] Wang, C.; Lu, J., Zhou, L.; Li, J.; Xu, J.; Li, W.; Zhang, L.; Zhong, X. and Wang, T. (2016): Effects of long-Term exposure to Zinc oxide nanoparticles on development, Zinc metabolism and biodistribution of minerals $(\mathrm{Zn}, \mathrm{Fe}, \mathrm{Cu}$, $\mathrm{Mn})$ in mice. PloS one, 11(10): e0164434.

[48] Huang, Y. L.; Lu, L.; Li, S. F.; Luo, X. G. and Liu. B. (2009): Relative bioavailabilities of organic zinc sources with different chelation strengths for broilers fed a conventional corn- soybean meal diet. J. Anim. Sci. 87:2038-2046.

[49] Fathi, M.; Haydari, M. and Tanha, T. (2016): Effects of zinc oxide nanoparticles on antioxidant status, serum enzymes activities, biochemical parameters and performance in broiler chickens. J Livestock Sci Technol, 4(2):7-13.

[50] Ahmadi, F.; Ebrahimnezhad, Y.; Sis, N.M. and Ghiasi, J. (2013): The effects of zinc oxide nanoparticles on performance, digestive organs and serum lipid concentrations in broiler chickens during starter period. Int $\mathrm{J}$ Biosci, 3:2329.

[51] Wu, Y.; Sun, Z.; Che, S. and Chang, H. (2004): Effects of zinc and selenium on 
the disorders of blood glucose and lipid metabolism and its molecular mechanism in diabetic rats. Wei Sheng Yan Jiu, 33(1): 70-73.

[52] Berg, J.M. and Shi, Y. (1996): The galvanization of biology: a growing appreciation for the roles of zinc. Sci, 271(5252): 1081-1085.

[53] Al-Daraji, H. J. and Amen, M. H. (2011): Effect of di-etary Zinc on certain blood traits of broiler breeder chickens. Int $\mathbf{J}$ Poult Sci, 10(10): 807-813.

[54] Lowe, N.M.; Lowe, N.M.; Fraser, W.D. and Jackson, M.J. (2002): Is there a potential therapeutic value of copper and zinc for osteoporosis? Proceedings of the Nutrition Society, 61:181-185.
[55] Tomaszewska, E., Muszyński, S.; Dobrowolski, P.; Kwiecień, M.; Winiarska-Mieczan, A.; Świetlicka, I. and Wawrzyniak, A. (2017): Effect of Zinc Level and Source (Zinc Oxide Vs. Zinc Glycine) on Bone Mechanical and Geometric Parameters, and Histomorphology in Male Ross 308 Broiler Chicken. Revista Brasileira de Ciência Avícola, 19 (1):159-170.

[56] Yu, Z.P., Le, G.W. and Shi, Y.H. (2005): Effect of zinc sulphate and zinc methionine on growth, plasma growth hormone concentration, growth hormone receptor and insulin-like growth factor-I gene expression in mice. Clinical and experimental pharmacology and physiology, 32(4): 273-278.

\section{الملخص العربي}

تأثير إضافة مصادر الزنك المختلفة على الأداء، وتوزيع المعادن داخل الجسم والجينات المتعلقة بالتمثيل الغذائي في بداري التسمين

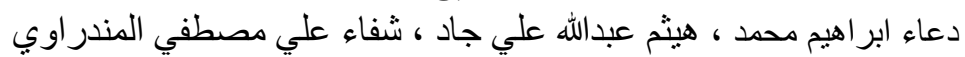

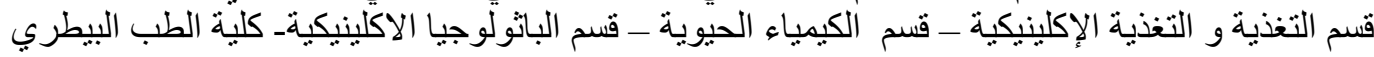

$$
\begin{aligned}
& \text { جامعة الزقازيق - مصر لئرلي }
\end{aligned}
$$

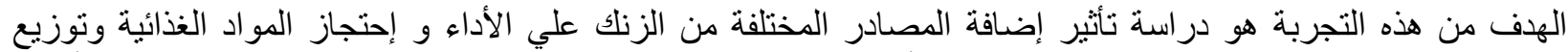

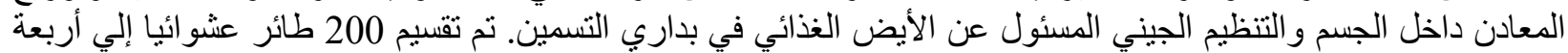

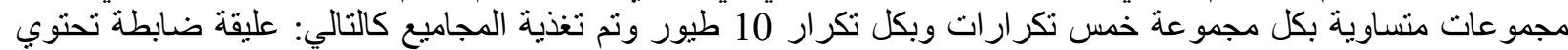

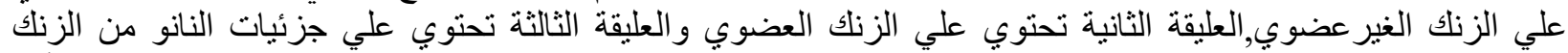

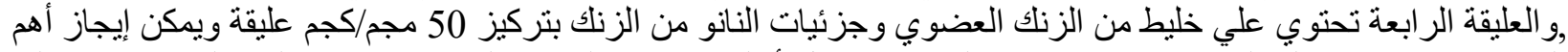

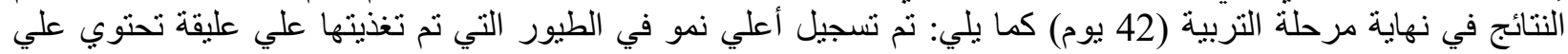

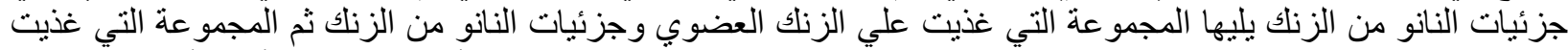

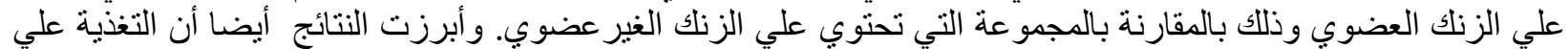

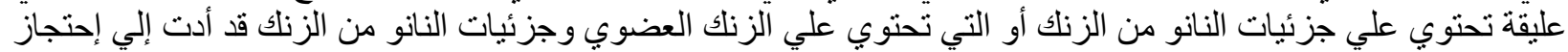

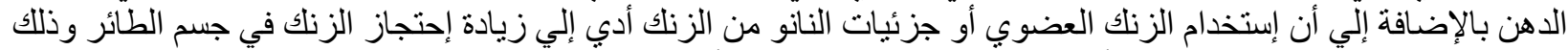

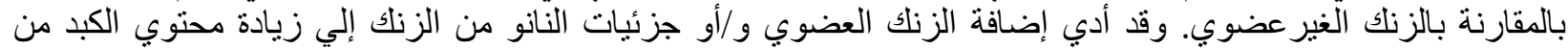

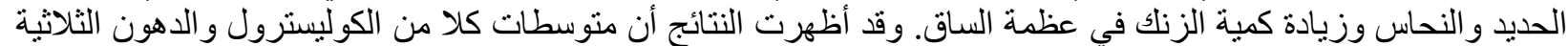

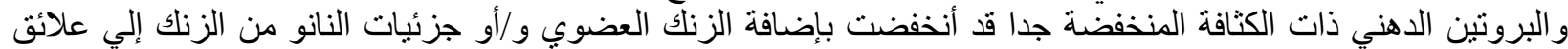

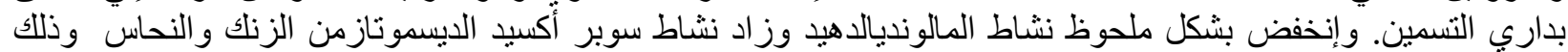

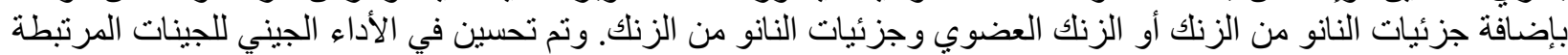

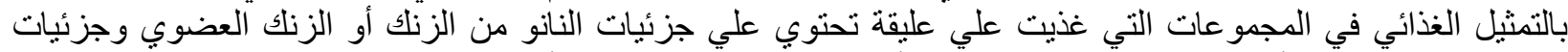

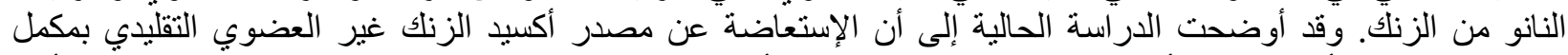

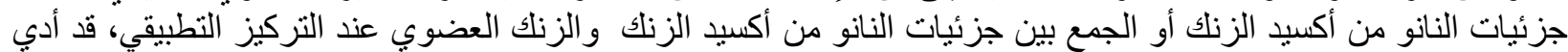

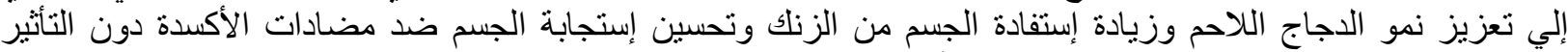

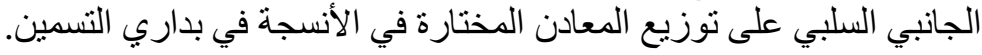

